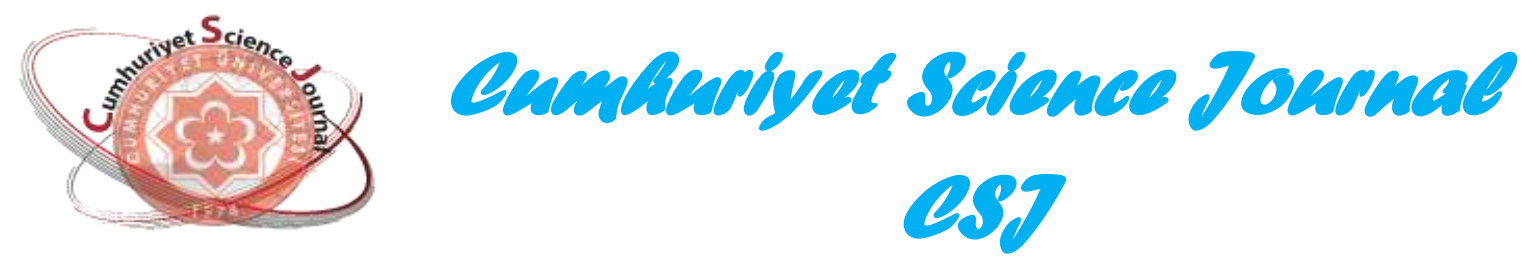

\title{
Investigation of Wind Characteristics for Antalya Region by Using Weibull Distribution
}

\author{
Ahmet ÇA ĞLAR \\ Akdeniz University, Faculty of Engineering, Mechanical Engineering Department,07058 Antalya / TURKEY
}

Received: 21.09.2017; Accepted: 04.10.2017

http://dx.doi.org/10.17776/csj.349901

\begin{abstract}
The most widely used statistical method that is used to determine the wind energy potential for a specific region is Weibull distribution or probability function. Using two-parameter Weibull distribution function, wind characteristics such as mean wind speed and mean wind power can be forecasted. In this study, the mean wind speed and wind power potential for Antalya are determined using Graphical, Moment and Maximum Likelihood methods with the help of the data taken from Antalya-Elmalı Meteorological Station. In this way, predicting the wind energy potential of Antalya region, it is discussed whether the possible installation of a wind power plant is feasible or not in this area. The results obtained are evaluated by using error analysis methods that are the Coefficient of Determination $\left(\mathrm{R}^{2}\right)$ and Root Mean Squares Error (RMSE).
\end{abstract}

Keywords: Wind speed, wind power, Weibull distribution, graphical method, moment method.

\section{Antalya Bölgesi İçin Rüzgâr Karakteristiğinin Weibull Dağılımı Kullanılarak İncelenmesi}

Özet: Belirli bir bölgenin rüzgâr enerjisi potansiyelini belirlemede en yaygın kullanılan istatistiksel yöntem Weibull dağılım fonksiyonudur. İki parametreli Weibull dağılım fonksiyonu ile ortalama rüzgâr hızı, ve ortalama rüzgâr gücü gibi rüzgar karakteristikleri tahmin edilebilmektedir. Bu çalışmada, Antalya ili için ortalama rüzgâr hızı ve rüzgâr gücü potansiyeli grafik, moment ve maksimum olabilirlik yöntemleri kullanılarak Antalya-Elmalı Bölge Meteoroloji İstasyonu'ndan alınan veriler yardımıyla belirlenmiştir. Böylece Antalya Bölgesinin rüzgâr enerji potansiyeli tahmin edilerek olası bir rüzgâr enerjisi santrali kurulumunun uygun olup olmayacağı tartışılmıştır. Elde edilen sonuçlar için ortalama hata kareleri toplamı kökü (RMSE) ve belirlilik katsayısı $\left(\mathrm{R}^{2}\right)$ hata analizleri yapılmıştır.

Anahtar Kelimeler: Rüzgâr hızı, rüzgâr gücü, Weibull dağılımı, grafik yöntemi, moment yöntemi.

\section{INTRODUCTION}

Industrial development is an important factor for countries as an indicator showing their level of development. However, this development leads to an increase in energy consumption together itself. Fossil fuels are intensively used in order to meet the increasing energy demand. Inordinate use of fossil fuels causes both the release of greenhouse gases (carbon dioxide, methane, nitrous oxide, hydrofluorocarbons, perfluorocarbons etc.) to the atmosphere at high rates and an increase in the external dependency of our country due to depletion of reserves quickly. In this context, the use of renewable energy resources becomes vital. It is clear that renewable energy resources are more economical and more reliable as well as environment-friendly. On the other hand, the efficient use of these resources, energy savings and

\footnotetext{
* Corresponding author. Email address: acaglar@akdeniz.edu.tr

http://dergipark.gov.tr/csj $\quad$ (C) 2016 Faculty of Science, Cumhuriyet University
} 
technological developments regarding these manners are also required.

Wind energy is a renewable energy source that has been used at low rates and requires to be benefitted more to meet the energy deficit. Mean wind speed and wind energy estimations are made in order to investigate the wind potential of a specific region, which may be a town, city or country, before investing in wind power generators in that region. These estimations can be performed by using wind speed and direction data measured in the corresponding region. In recent years, intensive studies have been carried out for determining wind energy potential and statistical analyses region by region have been performed in Turkey as in other developing countries. Case assessments regarding wind potential have been made by using various distribution methods such as Weibull and Rayleigh distributions. In a study performed in Cameroon, Kidmo et al. [1] determined the wind energy potential of Garoua city by two-parameter Weibull distribution using the data obtained from the meteorological station in Garoua airport. The data include hourly mean wind speed for the period 2007-2012. In the study, the coefficients $k$ and $C$ are defined as shape and scale parameter respectively. As the solution method for estimating parameters, six methods are used, including Empirical Method (EM), Energy Pattern Factor Method (EPF), Graphical Method (GM), Maximum Likelihood Method (MLM), Moment Method (MM) and Modified Maximum Likelihood Method (MMLM). The error analysis of the estimations for goodness of fit is performed by using the chi-square test $\left(\chi^{2}\right)$, correlation coefficient $\left(\mathrm{R}^{2}\right)$, root mean square error (RMSE) and Kolmogorov-Smirnov test (KOL). According to the results obtained, EPF and MM methods give more accurate results for the determination of the shape and scale parameters required in the estimation of wind speed distribution. Consequently, it is concluded that the wind energy potential in Garoua is not enough to generate electricity power, but would be fruitful in producing community water supply, livestock watering, and agricultural irrigation if windmills were installed.
Bhattacharya and Bhattacharjee [2] who have studied on power generation and selection of location for installing wind turbine generators used two-parameter Weibull distribution to predict wind speed variations in a year. Linear Least Square Method (LLSM) and Maximum Likelihood Estimator (MLE) were used for the estimation of parameters. As an example, the data for the average daily wind speed of Kolkata city in India for 2009 March were selected. In calculations, $k$ and $c$ values were found as about 1,01 and 29,99 respectively by using LLSM and 1,91 and 1,34 by using MLE. At this point, a significant difference between scale parameters $(c)$ of two methods was observed. The reason for this difference was stated as that $k$ and median rank values tended to unity.

Mert et al. [3] analyzed the wind energy potential of Antakya region statistically. The wind data were obtained from Hatay Meteorological Station and included wind speed and direction values between 2002-2009 years. Two-parameter Weibull and Log-normal distributions were used for the analysis. As parameter estimation technique, Maximum Likelihood Estimation (ML) and Least Square Method (LSM) were used. Annual Weibull shape parameter $(k)$ varied between 1.96-2.12 for ML method and 2.34-2.53 for LSM method, while annual Weibull scale parameter $(c)$ varied between 2.71-3.07 (m/s) for ML method and 2.61-2.96 $(\mathrm{m} / \mathrm{s})$ for LSM method. For Log-normal distribution, annual location parameter $(\mu)$ varied between 0.72-0.84 for ML method and 0.72-0.86 for LSM method, while annual scale parameter $(\sigma)$ varied between 0.53-0.59 for ML method and 0.520.57 for LSM method. The error analysis of calculations were performed by using Coefficient of Determination $\left(\mathrm{R}^{2}\right)$ and Root Mean Square Error (RMSE) techniques. RMSE values for the Lognormal distribution function were found as 0.020014 and 0.016242 by the ML and LSM methods respectively, while RMSE values for the Weibull distribution function were calculated as 0.012081 and 0.014582 by ML and LSM methods respectively. Other hand, $\mathrm{R}^{2}$ values were obtained as $98 \%$ for Log-normal distribution, while they were obtained as $99 \%$ for Weibull distribution, in both methods (ML and LSM). In the study, it was 
stated that however the results from both approximations were close to each other, Weibull distribution with ML method gave the best results. As a result of the research, wind energy potential of Hatay-Antakya region is statistically found to be encouraging for production of electricity if wind turbines have low cut-in speed.

Another study on the determination of wind potential was performed by Kaplan [4]. He statistically analyzed the wind energy potential of Osmaniye region using Weibull and Rayleigh distribution functions. Hourly wind speed data in year 2013 measured by Osmaniye Meteorological Station were used for the analysis. Graphic and Moment methods were used for calculating the parameters of the both distributions. The author concluded that Weibull distribution gave better results than Rayleigh distribution. In Weibull distribution, shape (k) and scale (c) parameters were obtained as 1,0046 and $1,7744(\mathrm{~m} / \mathrm{s})$ respectively in Graphic method, while they were obtained as 1,6394 and 2,5391 (m/s) respectively in Moment method. Consequently, it has been pointed out that the wind energy potential in Osmaniye is statistically suitable for electricity production.

Korukçu [5] analyzed the wind energy potential and power density of Bababurnu, Belen, Datça ve Gökçeada. He used Rayleigh distribution for the calculations. Monthly mean wind velocity values measured at $50 \mathrm{~m}$ height were taken from Turkish State Meteorological Service for the years between 2000 and 2007. The power density for each four regions was calculated above $500 \mathrm{~W} / \mathrm{m}^{2}$ that was the recommended value by General Directorate of Electrical Power Resources Survey and Development Administration (EIE) for low costs. It was concluded that power density of Belen (1581 $\left.\mathrm{W} / \mathrm{m}^{2}\right)$ and Gökçeada $\left(1297 \mathrm{~W} / \mathrm{m}^{2}\right)$ were higher than that of other regions due to their high mean wind speed values. Gökçeada, Datça and Belen have high wind potential and have currently their own wind power plant.

In their study, Bilgili et al. [6] investigated statistically the wind energy density of Akhisar,
Bababurnu, Belen, Datça, Foça, Gelendost, Gelibolu, Gökçeada and Söke districts which are located in the southern, southwestern and western region of Turkey. The measured data were collected by EIE. The Weibull and Rayleigh probability density functions, and the WAsP (Wind Atlas Analysis and Application Program) packet program were used for wind power density estimations. They also compared the results obtained by the models with the measured data. The Weibull model and WAsP program were seen to provide better estimations than Rayleigh model for all stations. It was consequently concluded that these regions had a reasonable wind power potential and they were suitable for the installation of wind energy plants.

Kurban et al. [7] studied the changes in the wind speed and power in 2005 July, August, September and December in İki Eylül Campus of Anadolu University in Eskişehir. They used Weibull distribution whose parameters were found by using Moment Method. In the study, a preliminary research for the wind energy potential of Eskişehir region was completed. Within the four months examined, August had the highest mean wind speed and hence the highest wind power was obtained in this month. Mean wind speed was observed to be above $3 \mathrm{~m} / \mathrm{s}$ for all the months. Consequently, the feasibility of wind energy potential of Eskişehir region to install an electricpower plant is confirmed with the results obtained.

In the literature, there are a lot of studies on the estimation of wind potential of different locations. In brief, the wind potentials of Bilecik [8], Çanakkale [9], Eskipazar [10], Galicia in Spain [11], Balıkesir [12], Niğde-Ulukışla and İstanbulGöztepe [13], Kudat and Labuan in Malaysia [14], Tabriz and Ardabil in Iran [15], and Liguria in Italy [16] were statistically investigated. The majority of these studies were performed using by Weibull and Rayleigh distributions. Apart from these distributions, there are other techniques used in estimating the wind potential of a specific region. Artificial neural network (ANN) is one of the important methods in this respect. Nezhad et al. [17] recommended an applied model for 
forecasting wind speed with the help of one-year wind speed and temperature data obtained from Kerman Meteorological Station in Iran by using ANN in their study. The obtained results indicate that this method is quite satisfactory for wind speed estimation. The results also show that the forecasting error is acceptable and ANN method is a good way to forecast short-term forecasting of electricity market price.

In this study, the annual changes in the wind speed and wind power potential, and so wind characteristics for Antalya are determined using Graphical, Moment and Maximum Likelihood methods with the help of the data taken from Antalya-Elmal1 Meteorological Station. In this way, predicting the wind energy potential of Antalya region, it is discussed whether the possible installation of a wind power plant is feasible or not in this area. The results obtained are evaluated by using error analysis methods that are the Coefficient of Determination $\left(\mathrm{R}^{2}\right)$ and Root Mean Squares Error (RMSE). No any significant research for the investigation of the wind potential of Antalya region has been carried out before in the literature.

\section{MATERIAL AND METHODS}

In practice, there are various methods to determine the wind energy potential of a region. Wind speed distribution measurement or frequency distribution is used in order to determine the wind potential of a specific region if possible. If not, wind speed distribution can be presented by other analytic distribution functions. Weibull distribution function is one of these functions. Due to its simple and flexible application as well as giving results close to actual data, Weibull distribution is widely accepted in the wind energy analysis [18]. In this study, Weibull distribution function is therefore used to estimate the wind characteristics. Graphical, Moment and Maximum Likelihood methods are used to find the shape and scale parameters of Weibull distribution function. These methods are chosen regarding the conclusions in the literature. In the light of similar studies performed before, it can be observed that the results obtained by both methods are quite consistent with the actual values.

Probability density function is a mathematical function that defines the distribution of wind speeds. A probability function is defined as the derivative of the cumulative probability distribution function as shown in the following equation [4]:

$$
p(v)=P^{\prime}(v), \quad 0<v<\infty
$$

where $p(v)$ is the probability function of measured wind speed $(v)$, and $P(v)$ is the cumulative probability distribution function. The general forms of $p(v)$ and $P(v)$ functions for two-parameter Weibull distribution are [4]

$$
p(v)=\left(\frac{k}{c}\right)\left(\frac{v}{c}\right)^{k-1} \exp \left[-\left(\frac{v}{c}\right)^{k}\right]
$$

and

$$
P(v)=1-\exp \left[-\left(\frac{v}{c}\right)^{k}\right]
$$

respectively. In these equations, $k$ and $c$ are the shape and scale parameters of Weibull distribution, respectively. These parameters should be firstly found in order to determine the mean wind speed and energy potential. For this aim, Graphical, Moment and Maximum Likelihood methods are respectively applied below.

\subsection{Graphical Method}

In Graphical method, the parameters of Weibull distribution are found by drawing a graph which is curve fitting of a particular distribution plot close to a straight line. Linear regression is applied by the linearization of Equation (3). In order to write Equation (3) in a linear form, the logarithms on both sides of the equation are taken twice as follows [4]:

$$
\begin{gathered}
-\left(\frac{v}{c}\right)^{k}=\ln [1-P(v)] \\
k \ln (v)-k \ln (c)=\ln [-\ln [1-P(v)]]
\end{gathered}
$$


Here, if $x, y, A$ and $B$ are defined as $x=\ln (v)$, $y=\ln [-\ln [1-P(v)]], \quad A=k \quad$ and $\quad B=-k \ln (c)$ respectively, the linear equation $y=A x+B$ can be obtained. The coefficients of this linear equation can be calculated by using linear regression method as mentioned above. Thus, the shape parameter $(k)$ can be directly found as equal to $A(k=A)$ while the scale parameter $(c)$ can be calculated as follows [4]:

$$
c=\exp (-B / A)
$$

It should be noted that $P(v)$ values are required to be determined to be able to apply the Graphical method. $P(v)$ values can be determined by using $p(v)$ values that can be calculated by the following equation using wind speed frequency for each 1 $\mathrm{m} / \mathrm{s}$ interval in the measured range [4]:

$$
p_{i}(v)=\frac{f_{i}}{\sum_{i=1}^{N} f_{i}}
$$

where $f$ is the wind speed frequency at a certain interval. $P(v)$ is then be found as follows:

$$
P_{i}(v)=p_{i}(v)+P_{i-1}(v)
$$

After determining the parameters $k$ and $c$, one can find the mean wind speed $\left(v_{m}\right)$ and wind energy potential $\left(P_{w}\right)$ by using the following equations [4]:

$$
\begin{gathered}
v_{m}=c \Gamma\left(1+\frac{1}{k}\right) \\
P_{w}=\frac{1}{2} \rho c^{3} \Gamma\left(1+\frac{3}{k}\right)
\end{gathered}
$$

where $\rho$ is the density of air $\left(\mathrm{kg} / \mathrm{m}^{3}\right)$ at the altitude of measurement point. $\Gamma$ is gamma function and expressed as follows [1]:

$$
\Gamma(x)=\int_{0}^{\infty} t^{x-1} e^{-t} d t
$$

and can also be determined analytically by [1]

$$
\Gamma(x)=\left(x^{x-1} \sqrt{2 \pi x}\right)\left(e^{-x}\right)\left(1+\frac{1}{12} x+\frac{1}{288} x^{2}-\frac{139}{51840} x^{3}+\ldots\right)
$$

\subsection{Moment Method}

One other method used in determining the parameters of Weibull distribution is Moment method. In this method, $k$ and $c$ parameters are determined by means of the mean wind speed $\left(v_{m}\right)$ and standard deviation $(\sigma)$ of wind data. The scale parameter $c$ can be found as follows [4]:

$$
c=\frac{v_{m}}{\Gamma\left(1+\frac{1}{k}\right)}
$$

while the shape parameter $k$ can be found by [4]

$$
k=\left(\frac{\sigma}{v_{m}}\right)^{-1.086}
$$

where $v_{m}$ and $\sigma$ are defined as:

$$
\begin{gathered}
v_{m}=\frac{1}{n} \sum_{i=1}^{n} v_{i} \\
\sigma=\sqrt{\frac{1}{n-1} \sum_{i=1}^{n}\left(v_{i}-v_{m}\right)^{2}}
\end{gathered}
$$

respectively. After finding Weibull parameters, the wind energy potential can be calculated by Equation (9).

\subsection{Maximum Likelihood Method}

Another method for determination of Weibull parameters is Maximum Likelihood method. This method offers an iterative solution. Shape and scale parameters can be calculated by the following expressions [9]:

$$
\begin{aligned}
& k=\left(\frac{\sum_{i=1}^{n} v_{i}^{k} \ln \left(v_{i}\right)}{\sum_{i=1}^{n} v_{i}^{k}}-\frac{\sum_{i=1}^{n} \ln \left(v_{i}\right)}{n}\right)^{-1} \\
& c=\left(\frac{1}{n} \sum_{i=1}^{n} v_{i}^{k}\right)^{1 / k}
\end{aligned}
$$

In this method, zero velocities are eliminated from the data since the method cannot give a solution for $v=0$. 


\section{RESULTS AND DISCUSSIONS}

The wind speed and energy potential estimations for Antalya region are performed by using the data taken from Antalya-Elmalı Meteorological Station for one-year period between July 2016-June 2017. The data contain hourly wind speed values in $\mathrm{m} / \mathrm{s}$. In Graphical method, the distribution of wind speed is divided into $1 \mathrm{~m} / \mathrm{s}$ intervals. The frequency $\left(f_{i}\right)$ of each interval is determined and probability functions $p_{i}(v)$ are then obtained. Using $p_{i}(v)$ values, cumulative probability distribution functions $P_{i}(v)$ values can be determined. After that, $\mathrm{x}$ versus $\mathrm{y}$ graph is plotted using the procedure given in Part 2.1, and the coefficients $A$ and $B$ and hence the parameters $k$ and $c$ can be found. Finally, the mean wind speed and wind energy potential can be calculated using Equations (8) and (9). Table 1 shows wind speed distribution, frequency, probability function and cumulative probability distribution function while Figure 1 shows $\mathrm{x}$ vs $\mathrm{y}$ plot.

Table 1. Frequency, probability function and cumulative probability distribution function for wind speed intervals (for July 2016June 2017 period).

\begin{tabular}{cccccc}
\hline $\boldsymbol{i}$ & $\boldsymbol{v}_{\boldsymbol{i}}(\mathbf{m} / \mathbf{s})$ & $\boldsymbol{f}_{\boldsymbol{i}}$ & $\boldsymbol{v}_{\boldsymbol{m}, \boldsymbol{i}}(\mathbf{m} / \mathbf{s})$ & $\boldsymbol{p}_{\boldsymbol{i}}(\boldsymbol{v})$ & $\boldsymbol{P}_{\boldsymbol{i}}(\boldsymbol{v})$ \\
\hline 1 & $0-1$ & 3976 & 0,59 & 0,474067008 & 0,474067008 \\
2 & $1-2$ & 2938 & 1,37 & 0,350304042 & 0,824371050 \\
3 & $2-3$ & 986 & 2,36 & 0,117562895 & 0,941933945 \\
4 & $3-4$ & 330 & 3,39 & 0,039346608 & 0,981280553 \\
5 & $4-5$ & 123 & 4,34 & 0,014665554 & 0,995946107 \\
6 & $5-6$ & 25 & 5,35 & 0,002980804 & 0,998926911 \\
7 & $6-7$ & 8 & 6,38 & 0,000953857 & 0,999880768 \\
8 & $7-8$ & 1 & 7,20 & 0,000119232 & 1 \\
\hline
\end{tabular}

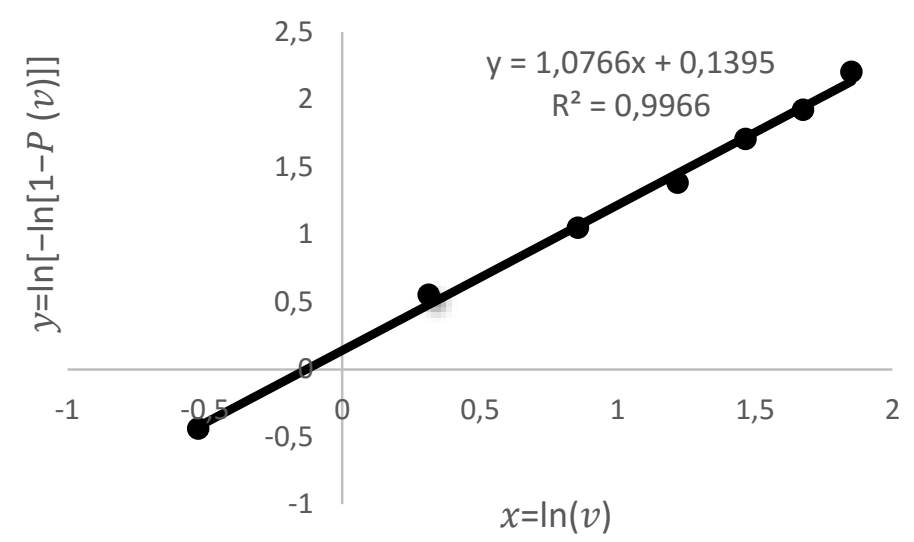

Figure 1. Linearization of Weibull distribution function in Graphical method.

The coefficients of the linear equation derived by linearization of Weibull distribution can be seen in Figure 1. According to these results, the shape and scale parameters are obtained as $k=1.0766$, $c=0.8785 \mathrm{~m} / \mathrm{s}$. On the other hand, the mean wind speed and wind energy potential are obtained as $v_{m}=0.8539 \mathrm{~m} / \mathrm{s}$ and $P_{w}=1.7248 \mathrm{~W} / \mathrm{m}^{2}$. Density of air is taken as $\rho=1.102 \mathrm{~kg} / \mathrm{m}^{3}$ in the calculation of wind energy potential.

In Moment method, firstly the mean wind speed and standard deviation are obtained as $v_{m}=1.2575$ $\mathrm{m} / \mathrm{s}$ and $\sigma=0.9069$. $k$ and $c$ parameters are then 
found as $k=1.4261, c=1.3835 \mathrm{~m} / \mathrm{s}$. The wind energy potential (or power density) is finally determined as $P_{w}=3.2169 \mathrm{~W} / \mathrm{m}^{2}$. In Maximum Likelihood method, $k$ and $c$ parameters are determined as $k=1.6061, c=1.4691 \mathrm{~m} / \mathrm{s}$ while the mean wind speed and energy potential are found as $v_{m}=1.3062 \mathrm{~m} / \mathrm{s}$ and $P_{w}=3.1039 \mathrm{~W} / \mathrm{m}^{2}$. The results for three methods are summarized in Table 2.

Table 2. Wind characteristics for Graphical and Moment methods and actual values.

\begin{tabular}{lllll}
\hline Parameter & Graphical Method & Moment Method & Max. Likelihood Method & Measured \\
\hline$k$ & 1.0766 & 1.4261 & 1.6061 & - \\
$c(\mathrm{~m} / \mathrm{s})$ & 0.8785 & 1.3835 & 1.4691 & - \\
$v_{m}(\mathrm{~m} / \mathrm{s})$ & 0.8539 & 1.2575 & 1.3062 & 1.2575 \\
$P_{w}\left(\mathrm{~W} / \mathrm{m}^{2}\right)$ & 1.7248 & 3.2169 & 3.1039 & 3.4642 \\
\hline
\end{tabular}

The variation of probability functions with increasing wind speed is given in Figure 2 for the comparison of Weibull distribution estimations with the measured data. Results for Moment method seem to be closer the actual values than that for the other methods.

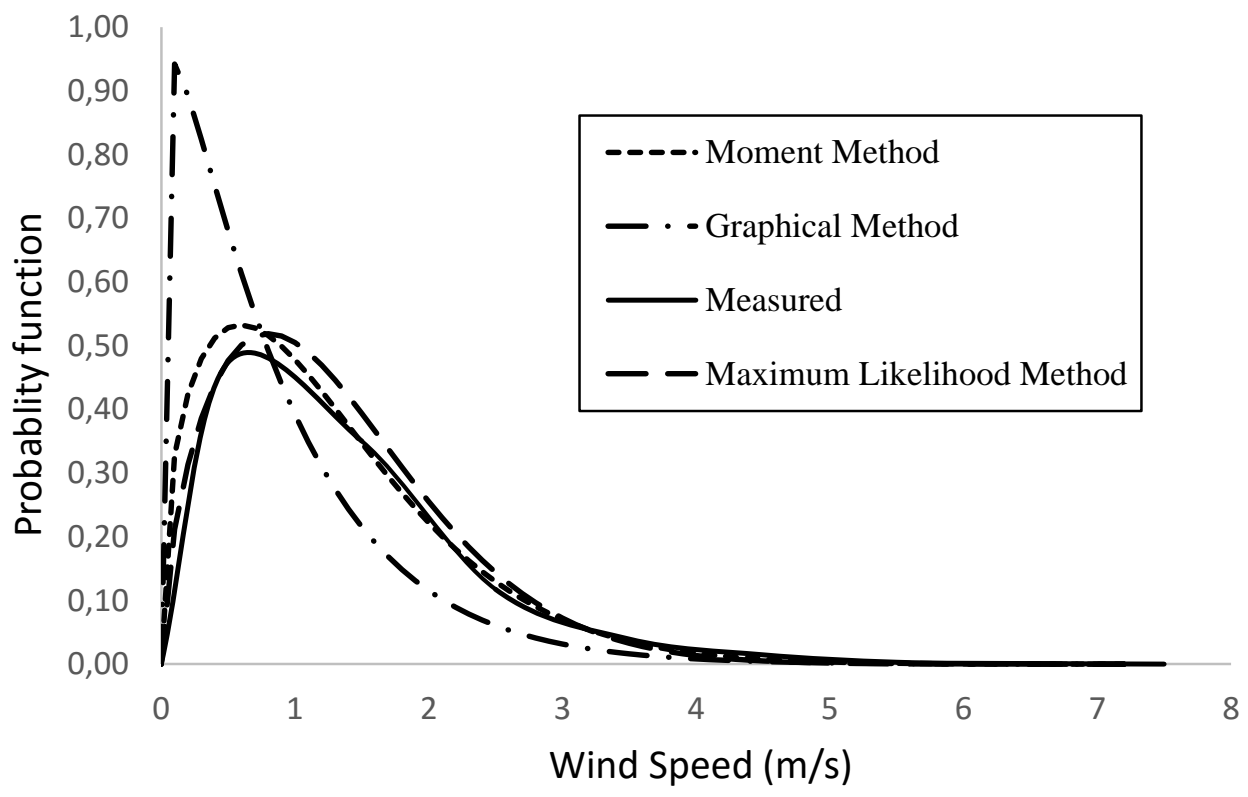

Figure 2. Variation of probability functions with wind speed.

\section{ERROR ANALYSIS}

In order to determine which one of the methods used in calculating Weibull parameters gives a better result, an error analysis has been carried out. In this study, two methods are used for the error analysis: one is the Coefficient of Determination $\left(\mathrm{R}^{2}\right)$ and the other is the Root Mean Squares Error (RMSE). The Coefficient of Determination is calculated by the following expression:

$$
R^{2}=1-\frac{\sum_{i=1}^{n}\left(y_{i}-x_{i}\right)^{2}}{\sum_{i=1}^{n}\left(y_{i}-\bar{y}\right)^{2}}
$$

The Root Mean Squares Error is calculated by the following expression: 


$$
R M S E=\sqrt{1-\sum_{i=1}^{n}\left(y_{i}-x_{i}\right)^{2}}
$$

In these equations, $y, x$ and $\bar{y}$ represent the measured value, estimated value and mean of measured values, respectively. The results of the error analysis are shown in Table 3.

Table 3. Error analysis results for the estimation of wind speed by Weibull distribution.

\begin{tabular}{llll}
\hline $\begin{array}{l}\text { Analysis } \\
\text { Method }\end{array}$ & $\begin{array}{l}\text { Graphical } \\
\text { Method }\end{array}$ & $\begin{array}{l}\text { Moment } \\
\text { Method }\end{array}$ & $\begin{array}{l}\text { Max. } \\
\text { Likelihood } \\
\text { Method }\end{array}$ \\
\hline$R^{2}$ & 0.8675 & 0.9675 & 0.9638 \\
$R M S E$ & 0.0416 & 0.0278 & 0.0283 \\
\hline
\end{tabular}

For a good analysis, $R^{2}$ should be close to unity while RMSE value should be close to zero. As seen in Table 3, Moment method gives the best results. When the other methods are compared to each other, Maximum Likelihood method gives better results than Graphical method.

\section{CONCLUSIONS}

There is a lack of investigation in the literature for determining the wind potential of Antalya region using any methods both theoretically and experimentally. This study covers the estimation of mean wind speed and power potential for Antalya region using one-year hourly wind speed data measured by the regional station of the Turkish Meteorological Service between July 2016 and June 2017.

Weibull distribution method is used to estimate the wind characteristics. In order to determine the shape and scale parameters of Weibull distribution function, Graphical, Moment and Maximum Likelihood methods are applied. As a result of this study, it is concluded that Moment method gives the best results and Maximum Likelihood method follows it. As compared to the wind power potential $\left(P_{w}\right)$ value calculated by the measured data, the result obtained by Moment method is very close to the actual value. The error analysis indicators, i.e. $R^{2}$ and $R M S E$, also confirm Moment method to be more appropriate in estimating the mean power density of Antalya. It should be noted that any other method might give better results for any other region or different data sets for the same region.

According to the results obtained, the wind energy potential of Antalya has remained at low rates during the period in question. The reason for this may be the use of hourly mean wind speed data in this study, whereas many studies use maximum wind speed data. Using the mean data, however, more realistic results can be obtained before investing in wind turbines in that region. Moreover, a single year or measurement point may not give a general idea about the characteristics of a big city.

\section{REFERENCES}

[1]. Kidmo D.K., Danwe R., Doka S.Y., Djongyang N., Statistical analysis of wind speed distribution based on six Weibull Methods for wind power evaluation in Garoua, Cameroon, Revue des Energies Renouvelables 2015; 18: 105-125.

[2]. Bhattacharya P., Bhattacharjee R., A study on Weibull distribution for estimating the parameters, Journal of Applied Quantative Methods 2010; 5: 234-241.

[3]. Mert İ., Karakuş C., Peker F., Antakya bölgesi rüzgar karakteristiğinin incelenmesi, Dicle Üniversitesi Mühendislik Fakültesi Mühendislik Dergisi 2014; 5(1): 13-22.

[4]. Kaplan Y.A., Rayleigh ve Weibull dağılımları kullanılarak Osmaniye bölgesinde rüzgar enerjisinin değerlendirilmesi, Süleyman Demirel Üniversitesi Fen Bilimleri Enstitüsü Dergisi 2016; 20: 62-71.

[5]. Korukçu M.Ö., Türkiye'de dört yerleşim yeri için rüzgâr enerjisi potansiyelinin belirlenmesi, Uludağ Üniversitesi Mühendislik-Mimarlık Fakültesi Dergisi 2011; 16: 117-126.

[6]. Bilgili M., Şahin B., Şimşek E., Türkiye'nin güney, güneybatı ve batı bölgelerindeki rüzgar enerjisi potansiyeli, Isı Bilimi ve Tekniği Dergisi 2010; 30: 01-12.

[7]. Kurban M., Kantar Y.M., Hocaoğlu F.O., Weibull dağılımı kullanılarak rüzgar hız ve güç yoğunluklarının istatistiksel analizi, 
Afyon Kocatepe Üniversitesi Fen Bilimleri Dergisi; 7(2): 205-218.

[8]. Dokur E., Kurban M., Wind speed potential analysis based on Weibull distribution, Balkan Journal of Electrical \& Computer Engineering 2015; 3(4): 231-235.

[9]. Akdağ S.A., Güler Ö., Calculation of wind energy potential and economic analysis by using Weibull distribution-A case study from Turkey. Part 1: Determination of Weibull parameters, Energy Sources, Part B: Economics, Planning, and Policy 2009; 4(1): 1-8.

[10].Köse B., Güneşer M.T., Yazıcı M., Yılmaz S.H., Eskipazar rüzgar enerjisi potansiyelinin Rayleigh, Lognormal ve Weibull dağılım modeli kullanarak tahminlenmesi, 3rd International Symposium on Innovative Technologies in Engineering and Science (ISITES-2015), Spain 2015; Volume 1: 22512260.

[11].Carrillo C., Cidrás J., Dorado E.D., Montaño A.F.O., An approach to determine the Weibull parameters for wind energy analysis: the case of Galicia (Spain), Energies 2014; 7: 26762700.

[12].Karadeniz A., Eker M.K., Balıkesir-Balya meteoroloji istasyonu verileri kullanılarak Weibull fonksiyonu parametrelerinin 6 farklı metodla belirlenmesi, Dokuz Eylül Üniversitesi Mühendislik Fakültesi Fen ve Mühendislik Dergisi 2015; 17(3): 163-175.
[13].Usta İ., Kantar Y.M., Farklı olasılık yoğunluk fonksiyonları kullanarak rüzgar gücü potansiyelinin tahmini, Dokuz Eylül Üniversitesi Mühendislik Fakültesi Fen Ve Mühendislik Dergisi 2016; 18(3): 362-380.

[14].Islam M.R., Saidur R., Rahim N.A., Assessment of wind energy potentiality at Kudat and Labuan, Malaysia using Weibull distribution function, Energy 2011; 36(2): 985-992.

[15].Fazelpour F., Soltani N., Soltani S., Rosen M.A., Assessment of wind energy potential and economics in the north-western iranian cities of Tabriz and Ardabil, Renewable and Sustainable Energy Reviews 2015; 5: 87-99.

[16].Ouammi A., Dagdougui H., Sacile R., Mimet A., Monthly and seasonal assessment of wind energy characteristics at four monitored locations in Liguria region (Italy), Renewable and Sustainable Energy Reviews 2010; 14(7): 1959-1968.

[17].Nezhad H.S., Zadeh A.K., Dehdiva S.S., Using artificial neural networks for forcasting wind speed changes in the city of Kerman, Cumhuriyet Üniversitesi Fen Fakültesi Fen Bilimleri Dergisi 2015; 36: 58-63.

[18].Gülersoy T., Çetin N.S., Menemen bölgesinde rüzgar türbinleri için Rayleigh ve Weibull dağılımlarının kullanılması, Politeknik Dergisi 2010; 13(3): 209-213. 